\title{
IUGA terminology and standardization: creating and using this expanding resource
}

\author{
Bernard T. Haylen ${ }^{1,2} \cdot$ Joseph K. S. Lee ${ }^{1}$ Robert M. Freeman ${ }^{3} \cdot$ Steven E. Swift $^{4}$
}

Received: 10 April 2017 / Accepted: 10 August 2017 / Published online: 8 September 2017

(C) The International Urogynecological Association 2017

\section{Introduction}

Standardized terminology, as used in communications by a scientifically focused association such as International Urogynecological Association (IUGA), is as basic and important as a dictionary is to the wider society. IUGA terminology documents, carefully prepared by experts in a long, consensus-based process, provide a valuable reference for IUGA members and others wishing to publish in the IUGA journal. When preparing an article for the Association's 40th anniversary Meeting in Nice in 2015 on history of IUGA Terminology and Standardization (T \& S), the increasingly rich legacy of the dedicated efforts of T \& S Committee and Working Group members becomes evident. "Utilizing" the sentence "Methods, definitions and units conform to the standards (jointly) recommended by the International

Bernard T. Haylen

bernard@haylen.co

Joseph K. S. Lee

josephkslee@gmail.com

Robert M. Freeman

bobfreeman@virginmedia.com

Steven E. Swift

swifts@musc.edu

University of New South Wales, Sydney, NSW, Australia

2 Suite 904, St Vincent's Clinic, 438 Victoria Street, Darlinghurst 2010, Australia

3 University of Plymouth, Plymouth, UK

4 Medical University of South Carolina, Charleston, SC, USA
Urogynecological Association (IUGA) (and International Continence Society-ICS), except where specifically noted," confirms that authors respect that legacy by checking that all definitions are accurate and correct outcome measures (if appropriate) have been used.

\section{History 1999-2008}

Whilst the early history of the IUGA T \& S Committee is not so well documented, it is commonly accepted that the original chair was Professor Ulf Ulmsten from Sweden. The committee was set up under the guidance of Dr. Harold Drutz from Canada, president and chairman of IUGA committees in 1999-2000. Early members included Peter Sand (USA), Bob Freeman (UK), and Eckhard Petri (Germany), all of whom were to become IUGA presidents. This perhaps indicates the importance of this committee within IUGA.

Around 2000-2002, IUGA's sister society, the ICS, was developing a report on the "Standardization of terminology for lower urinary tract function" encompassing terminology for men, women, and children in the one document [1]. Ulmsten, as T \& S chair and a coauthor of the ICS document [1], would have been updating the IUGA T \& S committee on its development, publication, and implementation. Freeman took over the chair from 2003 to 2005 , at which time there would have been no particular incentive for IUGA to seek alternative terminology documents.

Steven Swift (USA) served as IUGA T \& S chair from 2006 to 2008. At that time, the Pelvic Organ Prolapse Quantification (POP-Q) system from 1996 [2] was viewed as somewhat complex. An emphasis of the chair was to abridge the questionnaire and create a simplified POP-Q [3]. 


\section{History 2009-2017}

From 2008, there commenced negotiations with ICS, with a stronger IUGA input into female terminology beginning with a report on the terminology for female pelvic floor dysfunction. It was felt, in part, that several key female diagnoses may have been missing [4] from the 2002 ICS report [1]. The then chair of the ICS Standardization Committee, Dirk de Ridder, responded very positively to the joint IUGA-ICS initiative.

The Terminology for Female Pelvic Floor Dysfunction (PFD) [5], the initial product of that IUGA-ICS collaboration, was published simultaneously in the IUJ and Neurourology and Urodynamics (NAU) in January 2010. Its value in consolidating the definitions for symptoms, signs, investigations, imaging, and the six most common diagnoses have seen it become the core female PFD terminology document, with close to 1800 citations. This should be the document most commonly cited to confirm compliance in IUJ publications with IUGA-ICS terminology.

Complications related to the insertion of prostheses and grafts in pelvic floor surgeries [6] was a timely document, published in January 2011, to acknowledge the widespread clinical issues arising from the greatly expanded use of synthetic products in prolapse surgeries, in particular from around 2005. A category, time, and site (CTS) classification, as noted in Fig. 1, was created. This is the second most cited ( 280) IUGA document. Its native tissue equivalent [7] was published in April 2012, along with the important document on definitions, standardized outcome measures, and how to present results of prolapse surgeries [8]. This should be used in all studies of prolapse surgeries and cited when prolapse surgery trials are the subject.

Between 2012 and 2014, during the first author's second 3year term as chair, it was determined that areas of Terminology for PFD [12] needed to be expanded into separate IUGA-ICS terminology documents. Advertising and appointments of chairs and committees for working groups occurred in the following areas: female anorectal dysfunction (Sultan et al.); POP (Haylen et al.); conservative management of female pelvic floor dysfunction (Bo et al.); sexual health in women with pelvic floor dysfunction (Rogers et al.). It is pleasing that in early 2017, all but one of these documents had been published [9-12]. The relationship between documents are illustrated in Fig. 2.

In 2015, Joseph Lee became chair of the IUGA T \& S. The IUGA-ICS collaboration has continued after Dirk De Ridder

\begin{tabular}{|c|c|c|c|c|c|c|}
\hline \multicolumn{7}{|c|}{$\begin{array}{l}\text { Table 2: A CLASSIFICATION OF COMPLICATIONS RELATED DIRECTLY TO THE INSERTION OF } \\
\text { PROSTHESES (MESHES, IMPLANTS, TAPES) OR GRAFTS IN FEMALE PELVIC FLOOR SURGERY }\end{array}$} \\
\hline \multicolumn{7}{|c|}{ CATEGORY } \\
\hline & General De & & A (Asymptomatic) & B (Symptomatic) & $\mathrm{C}_{\text {(Infection) }}$ & D (Abscess) \\
\hline 1 & $\begin{array}{l}\text { Vaginal: no } \\
\text { Include promin } \\
\text { mesh fibre pal }\end{array}$ & $\begin{array}{l}\text { aration } \\
\text { Je to wrinkling or folding), } \\
\text { traction (shrinkage) }\end{array}$ & $\begin{array}{l}\text { 1A: Abnormal prosthesis or graft } \\
\text { finding on clinical examination }\end{array}$ & $\begin{array}{l}\text { 1B: Symptomatic e.g. Unusual } \\
\text { discomfort/ pain; dyspereunia } \\
\text { (either partner); bleeding }\end{array}$ & $\begin{array}{l}\text { 1C: Intection } \\
\text { (suspected } \\
\text { or actual) }\end{array}$ & $1 \mathrm{D}=$ Abscess \\
\hline 2 & Vaginal: sma & posure & 2A: Asymptomatic & 2B: Symptomatic & 2C: Intection & $2 \mathrm{D}=\mathrm{Abscess}$ \\
\hline 3 & Vaginal: larg & osure, or any extrusion & $\begin{array}{l}\text { 3A: Asymptomatic } \\
\text { 1-3Aa if no prosthesis or graft } \\
\text { related pain }\end{array}$ & $\begin{array}{l}\text { 3B: Symptomatic } \\
1-3 B(b-e) \text { if prosthesis or graft } \\
\text { related pain }\end{array}$ & $\begin{array}{l}3 C \text { : Intection } \\
1-3 C / 1-3 D(b-e) \\
\text { or graft related } p\end{array}$ & $\begin{array}{l}3 D=\text { Abscess } \\
\text { if prosthesis } \\
\text { gain }\end{array}$ \\
\hline 4 & $\begin{array}{l}\text { Urinary Trac } \\
\text { Including prost }\end{array}$ & $\begin{array}{l}\text { se or perforation } \\
\text { perforation, fistula and calculus }\end{array}$ & $\begin{array}{l}\text { 4A: Small intraoperative defect } \\
\text { e.g. bladder perforation }\end{array}$ & $\begin{array}{l}\text { 4B: Other lower urinary tract } \\
\text { complication or urinary retention }\end{array}$ & $\begin{array}{l}4 \mathrm{C} \text { : Ureteric or } \\
\text { urinary tract com }\end{array}$ & $\begin{array}{l}\text { upper } \\
\text { nplication }\end{array}$ \\
\hline 5 & $\begin{array}{l}\text { Rectal or Bc } \\
\text { including prost }\end{array}$ & $\begin{array}{l}\text { omise or perforation } \\
\text { perforation and fistula }\end{array}$ & $\begin{array}{l}\text { 5A: Small intraoperative defect } \\
\text { (rectal or bowel) }\end{array}$ & 5B: Rectal injury or compromise & $\begin{array}{l}\text { 5C: Small or Lar } \\
\text { or compromise }\end{array}$ & $\begin{array}{l}\text { rge bowel injury } \\
5 D=A b s c e s s\end{array}$ \\
\hline 6 & $\begin{array}{l}\text { Skin and / o } \\
\text { including disch }\end{array}$ & $\begin{array}{l}\text { keletal: complications } \\
\text { np or sinus tract tormation }\end{array}$ & $\begin{array}{l}\text { 6A: Asymptomatic, abnormal } \\
\text { finding on clinical examination }\end{array}$ & $\begin{array}{l}\text { 6B: Symptomatic e.g. dscharge, } \\
\text { pain or lump }\end{array}$ & $\begin{array}{l}\text { 6C: Infection e.g } \\
\text { formation }\end{array}$ & $\begin{array}{l}\text { 9. sinus tract } \\
6 D=\text { ADscess }\end{array}$ \\
\hline 7 & $\begin{array}{l}\text { Patient: com } \\
\text { including hem }\end{array}$ & emic compromise & $\begin{array}{l}\text { 7A: Bleeding complication } \\
\text { including haematoma }\end{array}$ & $\begin{array}{l}\text { 7B: Major degree of resuscitation } \\
\text { or intensive care }\end{array}$ & $\begin{array}{l}\text { 7C: Mortality" } \\
\text { "(additional com } \\
\text { - no site applical }\end{array}$ & $\begin{array}{l}\text { iclication } \\
\text { ble - } \mathbf{s} 0 \text { ) }\end{array}$ \\
\hline \multicolumn{7}{|c|}{ TIME (clinically diagnosed) } \\
\hline \multicolumn{3}{|c|}{ T1: Intraoperative to 48 hours } & \multicolumn{2}{|c|}{ T3: 2 months to 12 months } & \multicolumn{2}{|c|}{ T4: over 12 months } \\
\hline \multicolumn{7}{|c|}{ SITE } \\
\hline \multicolumn{2}{|c|}{$\begin{array}{l}\text { S1: Vaginal: } \\
\text { area of suture line }\end{array}$} & $\begin{array}{l}\text { 52: Vaginal: away from } \\
\text { from area of suture line }\end{array}$ & $\begin{array}{l}\text { S3: Trocar passage } \\
\text { Exception: Intra-abdominal (S5) }\end{array}$ & $\begin{array}{l}\text { S4: other skin or } \\
\text { musculoskeletal site }\end{array}$ & \multicolumn{2}{|c|}{ S5: Intra-abdominal } \\
\hline N.B. & \multirow{2}{*}{\multicolumn{6}{|c|}{$\begin{array}{l}\text { 1. Multiple complications may occur in the same patient. There may be early and late complications in the } \\
\text { same patient. Le. All complications to be listed. Tables of complications may often be procedure specific. } \\
\text { 2. The highest final category for any single complication should be used if there is a change over time. (patient } 888 \text { ) } \\
\text { 3. Urinary tract infections and functional issues (apart from 4B) have not been included. }\end{array}$}} \\
\hline & & & & CODE & $=T$ & $-\mathrm{S}$ \\
\hline
\end{tabular}

Fig. 1 Classification of complications related to insertion of prosthesis in female pelvic floor surgery 


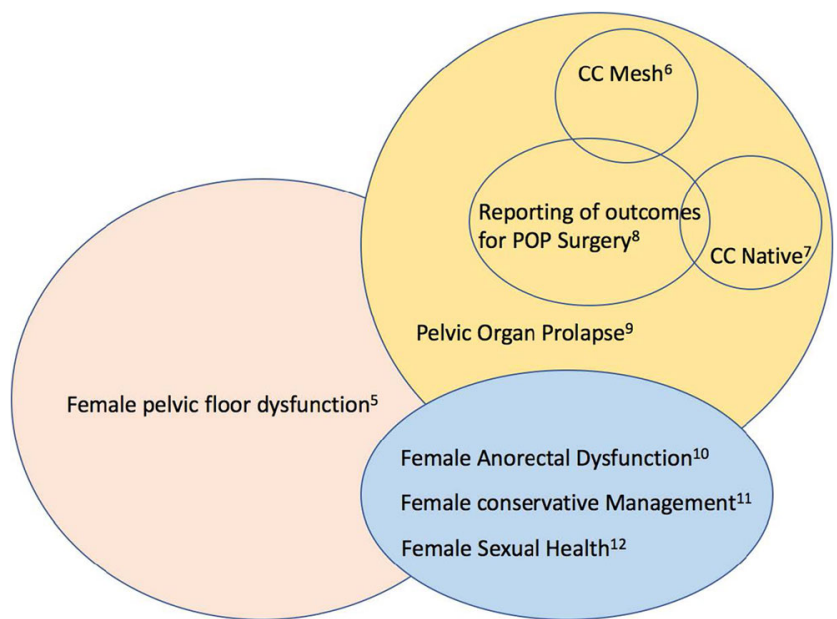

Fig. 2 Relationship between International Urogynecology Association/ International Continence Society (IUGA-ICS) terminology documents

with ICS Chair Marcus Drake (2001-2006) and from September 2016 the first author of this article.

\section{Current and future IUGA-ICS activity}

IUGA with their ICS partners now have a collection of eight key terminology documents. These have allowed tremendous interactions between members of the working groups and between the two societies. All chairs will attest to the different "labors of love" in producing the documents. Both societies are in a strong position going forward in regards to T\& $\mathrm{S}$. Ongoing principles are that: (i) documents be of the highest quality, contemporary, interesting, and a valuable contribution to the academic wealth of the respective organizations; (ii) definitions be accurate, concise, and - unless there is good cause - consistent. A current joint IUGA-ICS project is terminology related to a comprehensive female pelvic floor assessment (CFPFA). Future ICS-IUGA projects include terminology for: (i) pelvic floor fistulae; (ii) female obstetric trauma; (iii) laparoscopic pelvic anatomy.

\section{Creating and utilizing}

The authors of this editorial encourage all authors - whether contributing to this or any other journal - to use and cite the terminology/recommended outcome measures within these joint IUGA-ICS reports. In doing so, they confirm adherence to the correct terminology and methodology; and in the cases of graft complications and prolapse surgery outcomes, it will enable consistent reporting, facilitating more comparable studies for meta-analyses and systematic reviews, which have the potential to influence practice. The documents are available on the IUGA website (Resources/Terminology papers and Guidelines) and on the ICS website (Education/ Documents/Standardization/Current). As chairs of IUGA T $\& \mathrm{~S}$, present and past, we encourage IUGA members to look for an opportunity to take part in creating future documents by becoming part of an IUGA-ICS working group, which are regularly advertised. Composition of such documents allows a positive and fruitful academic interaction with colleagues from around the world.

\section{IUGA Terminology \& Standardization Committee Chairs}

Prof. Ulf Ulmsten (Chair T \& S, 2000-2002)

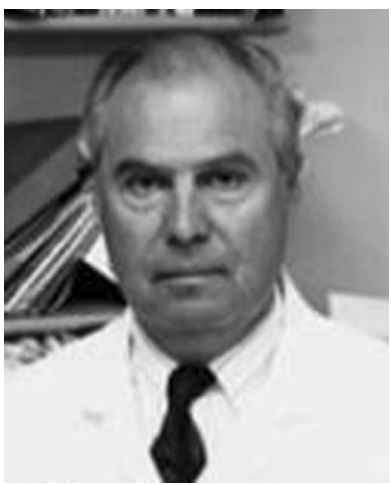

Prof. Bob Freeman (Chair T \& S, 2003-2005)

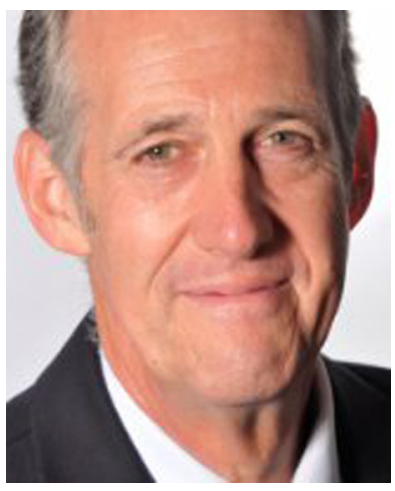

Prof. Steven Swift (Chair T \& S, 2006-2008)

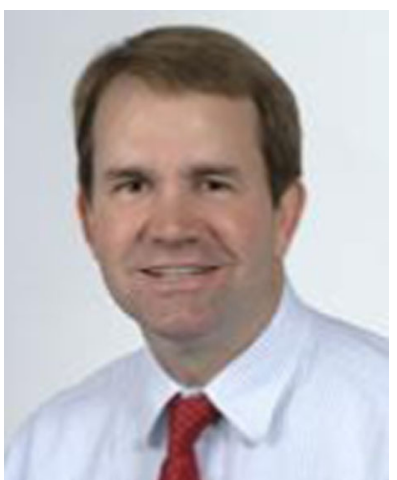


Prof. Bernie Haylen (Chair, T \& S, 2009-2014)

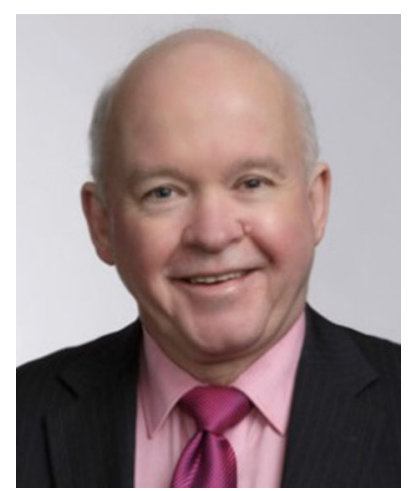

A/Prof. Joe Lee (Chair T \& S, 2015 - )

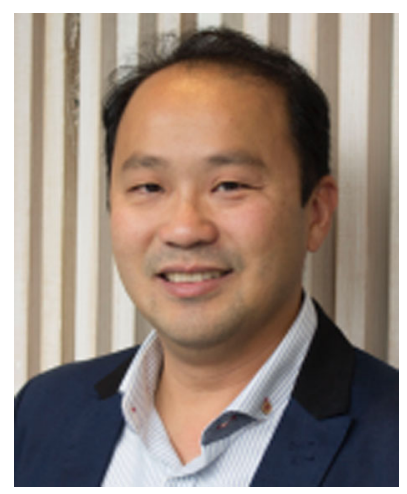

Acknowledgements The authors thank Dr. Vasukhi Sivagnanam and Dr. Angela Cross, from St Vincent's Hospital, Sydney, for their assistance in proofing and reference checking.

\section{Compliance with ethical standards}

\section{Conflicts of interest None}

\section{References}

1. Abrams P, Cardozo L, Fall M, Griffiths D, Rosier P, Ulmsten U, et al. The standardisation of terminology of lower urinary tract function. Report from the standardisation subcommittee of the international continence society. Neurourol Urodyn. 2002;21:16778.

2. Bump RC, Mattiasson A, Bo K, Brubaker LP, DeLancey JO, Klarskov $\mathrm{P}$, et al. The standardization of female pelvic organ prolapse and pelvic floor dysfunction. Am J Obstet Gynecol. 1996;175(1):10-1.

3. Swift S, Morris S, McKinnie V, Freeman R, Petri E, Scotti RJ, et al. Validation of a simplified technique for using the POP-Q pelvic organ classification system. Int Urogynecol J. 2006;17(6):615-20.

4. Haylen BT, Chetty N. International continence society 2002 terminology report. Have urogynecological diagnoses been overlooked? Int Urogynecol J. 2007;18(4):373-7.

5. Haylen BT, Freeman RM, de Ridder D, Swift SE, Berghmans B, Lee J, et al. An International Urogynecological Association (IUGA) - International Continence Society (ICS) Joint Report into the Terminology for Female Pelvic Floor Dysfunction. Int Urogynecol J, 21:5-26. Neurourol \& Urodyn. 2010;29:4-20.

6. Haylen BT, Freeman RM, Swift SE, Cosson M, Davila GW, Deprest J, et al. An international Urogynecological association (IUGA) / international continence society (ICS) joint terminology and classification of complications related directly to the insertion of prostheses (meshes, implants, tapes) and grafts in female pelvic floor surgery. Int Urogynecol J 22 (1):3-15. Neurourol Urodyn. 2011;30(1):2-12.

7. Haylen BT, Freeman RM, Lee J, Swift SE, Cosson M, Deprest J, et al. An international Urogynecological association (IUGA) / international continence society (ICS) joint terminology and classification of the complications related to native tissue female pelvic floor surgery. Int Urogynecol 23 (5):515-526. Neurourol Urodyn. 2012;31(4):406-14.

8. Toozs-Hobson P, Freeman R, Barber M, Maher C, Haylen BT, Athanasiou $\mathrm{S}$, et al. An international Urogynecological association (IUGA) / international continence society (ICS) joint report on the terminology for reporting outcomes of surgical procedures for pelvic organ prolapse. Int Urogynecol 23 (5): 527-535. Neurourol Urodyn. 2012;31(4):415-21.

9. Haylen BT, Maher CF, Barber MD, Camargo SFM, Dandolu V, Digesu A, et al. International Urogynecological association (IUGA) / international continence society (ICS) joint report on the terminology for pelvic organ prolapse (POP). Int Urogynecol J 27(2):165-194; erratum 27(4): 655-684. Neurourol Urodyn. 2016;35(2):137-68

10. Sultan AH, Monga A, Lee J, Emmanuel A, Norton C, Santoro G, et al. An international Urogynecological association (IUGA) / international continence society (ICS) joint report on the terminology for anorectal dysfunction in women. Int Urogynaecol J 28 (1):5-31. Neurourol Urodyn. 2017;36(1):10-34.

11. Bo K, Frawley H, Haylen BT, Abramov Y, Almeida F, Berghmans $\mathrm{B}$, et al. International Urogynecological association (IUGA) / international continence society (ICS) joint report on the terminology for the conservative and non-pharamacological Management of Female Pelvic Floor Dysfunction. Int Urogynecol J 28 (2): 191213. Neurourol Urodyn. 2017;36(2):221-44.

12. Rogers R, Pauls RN, Thakar R, Morin M, Kuhn A, Petri E, Fatton B, Whitmore K, Kinsberg S, Lee J. International Urogynecological Association (IUGA) / International Continence Society (ICS) Joint Report on the Terminology for the Sexual Health in Women with Pelvic Floor Dysfunction. (Under final review). 